\title{
VOTING ADVICE APPLICATIONS IN HUNGARY. VOKSKABIN IN THE MULTI-ELECTION YEAR 2014 AND BEYOND
}

\author{
Melani Barlai ${ }^{1}$
}

\begin{abstract}
The objective of the paper is to introduce the first Hungarian scientifically developed online voting advice application project Vokskabin (www.vokskabin.hu). It was established on the occasion of the Hungarian super election year 2014, when three elections - parliamentary, the European Parliament and the municipal elections - took place. As a first step the study describes the development phase of the project as well as its structure and purpose. Furthermore, it analyses the user-statistics of the answered questionnaires, generated by the online-tool, for all three Hungarian elections and for the two questionnaires "Equality of men and women in Hungary" and "Roma in Hungary" which were developed 2015 to keep the civic education aspect of Vokskabin alive and addressing politically and socially relevant issues like gender equality and minority situation, also outside the election period.
\end{abstract}

The paper raises two main questions: 1. Are there any regional differences of Vokskabin users' behavior? 2. How does Vokskabin influence the voting behavior (with focus on the electoral participation) and the political knowledge? This part of the study is based on survey questionnaires addressed to the users of Vokskabin.

In addition to the analysis of the statistics the paper aims to highlight the role of voting advice applications in general and the role of Vokskabin in particular, as means of civic education in the 21st century Hungarian society.

\section{Voting Advice Applications (VAAs)}

One of the main achievements of political and social development in modern Europe lies in the improvement of the decision-making process which is now open not only to the members of limited groups privileged by birth (emperors, kings, consultants, aristocrats) but also to those concerned. The idea of social equality became the breeding ground for innumerable ideas and movements across the world (African-American civil rights movement, suffragettes) who fought for the largest possible degree of self-determination and responsibility for their own lives: for the right to vote.

While there are still places where the fight for general, equal, free and secret elections is ongoing, in the modern knowledge-based societies of the 21 st century it is not our right to vote but rather our ability to make an informed decision which is becoming uncertain to an ever-increasing degree. This right and ability, in addition to compliance with census rules and the drawing up of constituency boundaries, has the potential to exert the most influence on what political forces, parties or interest groups we elect into (legislative) power. It is therefore absolutely essential for us,

\footnotetext{
${ }^{1}$ netPOL/Andrássy University Budapest, Pollack M. tér 3, H-1088 Budapest, melani.barlai@andrassyuni.hu
} 
the electorate, to familiarise ourselves with the party manifestos and to pay attention to both the social issues that concern us and to the solutions that the parties propose for such issues.

\subsection{International Examples}

In Europe, this thinking formed the basis for an initiative that was first implemented in the Netherlands, followed by Germany and Austria that uses easily accessible electronic tools to help people make their voting decisions in a simple but interactive way. The first voting guide was compiled by the Instituut Publiek en Politiek in the Netherlands in 1989. Initially it was paper-based but in 1998 it was put online. In 2002 Germany obtained the relevant licence and used the so-called Wahl-O-Mat for the first time at the general elections for the German parliament (Bundestagswahl).[4]

The Wahl-O-Mat has since become one of the most successful achievements of the Bundeszentrale für Politische Bildung.[5] Initially presented to political parties for completion, the questions on popular issues have been and still are being compiled by an independent group of researchers and young students at Heinrich Heine University.[13] The research team selected the final tests from questions where different answers were given by the political parties, i.e. where differences clearly showed in their views on social issues, politics or economics.

2009 saw great changes in the political voter guides in Germany since not just the political parties holding seats in the German parliament were entitled to share their views via the Wahl-O-Mat but also the parties registered for any elections, an approach that was adopted by the Hungarian Vokskabin application. The application was implemented in several German states in time for the state elections.[5] In Austria the Federal Ministry of Education, Arts and Culture [Bundesministerium für Unterricht, Kunst und Kultur] and the Donau-Universität Krems took upon themselves the task of initiating the creation of a publicly accessible VAA. In the context of the "Politikkabine" application, the main department for political communications [Department für Politische Kommunikation] at Donau-Universität is responsible for coordinating the journalists, statisticians and political scientists involved in the initiative. Compiled by the above department, the tests on popular issues which contain 20 to 25 questions provided a voting aid for the electorate preceding the Austrian elections.[7] The Politikkabine application was discontinued in 2014. The other popular VAA in Austria is Wahlkabine[27], which began in 2002, just like Wahl-O-Mat. As in Germany, the two Austrian VAAs aim to provide information to the Austrian people and present political content (election campaigns and party manifestos, policies and plans) to those interested. Similar to the method applied in Germany, the political parties and candidates are first required to respond to questions relating to social politics. Then the application compares their answers to the opinions of the voters who completed the test.

Similar initiatives were started in Anglo-Saxon countries, which, apart from certain variations in methodology, also focus on providing guidance to the electorate. In 2012 Taylor Peck and Nick Boutelier undertook the seemingly insurmountable task of constantly monitoring economic matters, domestic affairs and foreign policy in the USA, the UK, Australia, Canada and India, to establish the political views of those surveyed in these countries by means of tests similar to those previously mentioned. Nevertheless their methods differ fundamentally from the online VAA systems deployed in continental Europe as in their case, the political parties do not receive any tests or questions and the replies to the questions are inferred from communications in press conferences, party manifestos and interviews.[18] 


\section{Creation of the Hungarian VAA, Vokskabin}

In Hungary the need for and thinking about the creation of a voting guide application emerged prior to the start of the Vokskabin project. Political analyses, research studies and statistics have been available in Hungary in the past and numerous research institutes dealt with the run-up to the elections, the presentation of political manifestos and their analyses. These include, inter alia, the Political Capital Policy Research \& Consulting Institute, established in 2001, which focuses on analysis and consulting activities in Hungary[22], Iránytü Politikai és Gazdaságkutató Intézet [Compass Institute for Politics and Economic Research], established in 2011, which likewise strives to contribute to the development of the political and economic culture of the country in an unambiguous manner[20] for the Institute of Word Economics of the Hungarian Academy of Sciences [Magyar Tudományos Akadémia Világgazdasági Intézete], which deals with the impact that economic processes taking place on a global and EU level have for Hungary. Based on in-depth research work, it is precisely due to their level of detail and analytical character that these analyses failed and still fail to evolve into informative guides giving direction to large social groups.

This was the reason why in 2006 the idea was born to create an interactive VAA which initially came into being as Választási Iránytü [Vote Compass] for the 2010 general elections. The questions asked by Vote Compass were compiled by the market research institute Ipsos and the international Association for European Election Officials (ACEEEO). Based on this, six years ago voters received guidance in the form of tests containing 48 questions, to help them judge their political affiliation in a more confident manner.[1]

Started in the multi-election year 2014, Vokskabin was initially composed of a team of political scientists, historians and students who also primarily followed the German and Austrian examples, thereby creating a VAA based on international collaboration with the specific feature that one of its supported languages is German, so those interested in Hungary who live in German-speaking areas can stay abreast with what is going on. In contrast to the US term Voting Advice Application, which implies the provision of voting advice, Vokskabin distances itself from this interpretation and defines itself as a scientific, non-partisan online voting advice application (abbreviated: VAA) with the primary objective of providing guidance in the most important popular issues and helping users decide on the positions of the surveyed parties and their own opinions, particularly in election periods.

\subsection{Methodology of Vokskabin}

Those who complete the Vokskabin questionnaire get the chance to learn which political party and/or parties stand closest to or farthest from their own preferences. Via the Vokskabin online interface, visitors have the chance to respond to a set of 25 to 35 questions that change from time to time and are relevant in everyday life. The Vokskabin methodology follows the approach of the Austrian partner project POLITIKKABINE.AT. Importantly, this Austrian application does not record personal data, so as to ensure user anonymity. Based on the answers yes/no or "I don't know" the user learns the degree of identification with or divergence from the views of the political parties, which is shown as a percentage ranking in a graph once the set of questions has been completed. The match ratio is calculated by the application using the following equation: Pi (f, p) = aif $*$ aip. Based on this, the following reply combinations are possible: 


\begin{tabular}{|c|c|c|}
\hline $\begin{array}{l}\text { Political party } \\
\text { User }\end{array}$ & "Yes" & "No" \\
\hline "Yes" & 1 & -1 \\
\hline "No" & -1 & 1 \\
\hline
\end{tabular}

Figure 1: Points of accordance without weighting Source: Politikkabine.at 2012.

Different values are generated depending on the answer. When the answers of the political parties and of the user match, the value is 1 point, if they do not match, -1 point. The "I don't know" answers have no influence on the accordance or divergence value since the answer option "I don't know" is not accessible to political parties. When skipping a question, i.e. when a user does not choose any option for one or more questions, the application advises the user that the result will be calculated based on all the questions answered "yes" or "no".

As for the creators of the predecessors of Vokskabin, the primary objective was to lay down the basic principles and aims of the application. For Wahl-O-Mat, Politikkabine and Vokskabin, acting in good faith, impartiality and a non-partisan approach are indispensable. Consequently, based on the German example mentioned above all Hungarian political parties that registered for the 2014 general elections or for the European parliamentary elections were eligible to complete the questionnaire and attach brief explanations. Acting in good faith and impartiality are important first and foremost because the answers received from the political parties and the creation and analysis of the tests serve two purposes: to provide information and political education to the electorate in a playful form and to utilise the data collected in this manner for later research. Vokskabin's objectives include contributing to the transparency of Hungarian political life and providing information on the views of the political parties to the users. The main tool for achieving this is to strive for collaboration on a broad basis, and to this end political parties, the media, nongovernmental organisations and students are involved in the process not only in evaluating the questions and completing the questionnaires but at the very first stage, i.e. when the questionnaires are being elaborated and edited. In addition to all of the above, Vokskabin's most important undisclosed objective is probably to create openness in the young and first-time voters for public issues and to have them make informed decisions at general elections, European parliamentary elections and local elections.

In 2014 several initiatives akin to Vokskabin were launched. These included, for example, the site partkereso.hu which was launched by Nézőpont Intézet. It failed to achieve its aim due to a lack of impartiality and user anonymity and the erroneous programming of the application's search engine. As a result Nézőpont discontinued the project and closed the web interface of this search site. At the same time, a positive example worth mentioning is a questionnaire created by VS.hu for the general elections and the European parliamentary elections that contained 50 questions and which was designed to help voters decide on a political party ${ }^{2}$. Similarly to VS.hu, for the general elections the non-profit organisation K-Monitor [K-Monitor Közhasznú Egyesület] launched the questionnaire "Voksmonitor" which contained 50 questions. ${ }^{3}$ Voksmonitor was the only application launching a voting aid regarding the candidates for the election of Budapest mayor and it was the only voter guide that created a guidance questionnaire for the local elections on 12 October 2014.

\footnotetext{
${ }^{2}$ The site is no longer available.

${ }^{3}$ Available: http://voksmonitor.hu/2014-es-orszaggyulesi-valasztas/\#p2
} 


\section{VAA impact studies}

There is little Hungarian literature as yet on the presentation of VAAs, their impacts and their scientific aspects. Foreign scientific literature focuses specifically on examining the mechanism of action of VAAs, and Stefaan Walgrave distinguishes 4 areas[26]: firstly, the effect on the voters, secondly the effect on the political parties/candidates, thirdly the effect on the electoral campaign and fourthly the effect on science. In the voter impact study we present another 3 categories. In the first category we review the influence of online VAAs on the awareness of the users, on the manifestos of the political parties and/or candidates and on public issues with regard to the current political situation in general. In addition, we are able to work in one of the most important areas of research and study the impact of VAAs on voter turnout and decisions. This includes, for example, questions examining whether the impact of the VAA on voter turnout is positive or not or if VAAs have an influence on a potential change in the party and/or candidate affiliation of the user and if so, to what extent. This mechanism of action is documented in various research studies [12][2][25]. Naturally, relevant studies point out that VAAs can have an influence on the manifestos and campaigns of the political parties and candidates. It is not unusual in countries like Germany, the Netherlands, Austria or Switzerland, where online VAA applications can look back at decades of tradition and have tens of millions of users preceding a given election, that the political stakeholders consciously utilise VAAs for the marketing of their individual and their parties' manifestos.

The 1st Vokskabin impact study, a questionnaire named "Roma in Hungary", was published in December 2015. The users were asked questions in connection with voting mechanisms of actions, in particular the influence of Vokskabin on political knowledge, voter turnout and decisions. A total of 1,240 people participated in the survey held between 9 December 2015 and 4 January 2016. However, before presenting the results of the impact study it is worth considering the usage levels of Vokskabin.

\subsection{Vokskabin usage level}

Utilising the data at our disposal we can provide an overview of the number of people who in the period from 4 March 2014 (the time the site first went live) to 12 October 2014 (the time of the local elections) completed the Vokskabin questionnaire for the general elections, the European parliamentary elections and the local elections, and what pattern of regional distribution emerges (country, region, town or city) when considering the questionnaires completed separately for the general elections, the European parliamentary elections and the local elections, respectively. When referring to users we mean all visitors to the Vokskabin website who completed the questionnaire, either partly or in full, and arrived at the last page, i.e. the results page. Visitors to the site who did not start completing the questionnaire and merely browsed the site or who stopped completing it halfway through after having started were not included in the database. It is important to note that $15.6 \%$ of all users were returning users. However, this percentage figure does not allow us to define the regional distribution of the returning users. There is no facility in Google analytics to check single users and returning users separately. In this respect the regional distribution of the results may be distorted. Regarding the geographical features of the usage levels we examine both the Hungarian data and the more conspicuous foreign data. The data used in the research were provided by the software of Google analytics, which has been measuring the usage levels of the site and the regional distribution of the IP addresses since Vokskabin's launch on 4 March. 
Vokskabin compiled a questionnaire drawing on the 4 most important subject areas of the general elections ${ }^{4}$. Following its launch on 4 March, the questionnaire with 26 questions was completed by 27,757 respondents in total. On 5 March the site recorded the highest number of users in one day (more than 9,000), when following a press conference on the day before, numerous online articles reported on the launch of the site. The media reporting on Vokskabin included, among others, origo.hu, index.hu, 444.hu and a considerable number of Hungarian and foreign websites and blogs. In addition to this, the Budapest-based Civil Rádió presented the project in an interview.[6] While visitor and usage levels were initially high, a daily average of almost 1,000 people completed the set of questions until 6 April, the day of the elections, thereby exceeding the expectations of the project initiators. Some $14.2 \%$ of the users visited the site and used the application several times. This indicates that the playfulness of the application caught the attention of many and encouraged them to "self-test".

\subsubsection{Vokskabin foreign usage levels}

One striking feature that emerges when examining the application's usage levels is the large number of foreign IP addresses that the application was used from for the general elections. The data processed for the examination were those collected by Google analytics in the period from 4 March 2014 to 12 April 2014. One of the reasons why the usage levels of foreign users are so considerably high lies in the fact that the website is bilingual and the questionnaires, supporting materials and background information are available not only in Hungarian but also in German. This way, the bilingual layout attracted native German speakers who have an interest in Hungarian politics. Due to the weak economic environment, many Hungarians have moved to another country in past years, which serves as a further explanation for the extensive participation from outside Hungary. The 3 most popular target countries for Hungarian migrants are the United Kingdom, Germany and Austria.[21] Their number, according to a KSH flash estimate, amounts to 335,000, which includes Hungarian citizens who have a Hungarian residential address or who support a Hungarian household. Even so, the ratio of migrants who do not belong in either of the two above groups is extremely high. As a result they are not included in any surveys.[17] Since the number of votes cast by citizens residing abroad is quantified precisely, we work with these figures as baseline data in the study. A total of 24,119 (85\%) out of 28,161 Hungarian citizens who registered at the embassies cast their ballot. The most votes for the general elections were cast in London[14], where 5,371 voters registered to vote at an embassy or consulate and 4,435 of them actually cast their ballot on 6 April. Munich came 2nd with 2,580 embassy or consulate voters. In Brussels this number further decreased with 1,675 persons voting. 1,000 embassy or consulate voters were counted in Bern, Berlin and Vienna.[14]

Taking into account the voting behaviour of voters residing abroad, further examinations should be conducted on the completion of the Vokskabin general elections questionnaire by foreign users. The highest user activity outside Hungary was recorded in Austria, where 4.64\% of all users, i.e. 1,287 people, used the application. Germany came 2 nd with 929 respondents, i.e. $3.35 \%$ of all users. With a mere 371 completed questionnaires the United Kingdom came 3rd. The high activity levels in Austria become even more striking if we consider the populations of Austria ( 8.4 million), Germany (80.6 million) and the United Kingdom (64.1 million). Moreover, while London was by far the busiest embassy or consulate voting place for the general elections, it is interesting to note that the number of Vokskabin respondents was extraordinarily low here and accounted for a mere $1.34 \%$ of all users. This indicates that while the German version of the site was able to attract the non-

\footnotetext{
${ }^{4}$ Economy, democracy, political culture, domestic and foreign policy.
} 
Hungarian speakers in Austria and Germany, this was not possible in English-speaking regions due to the lack of an English version. For this reason it can be assumed that the questionnaires submitted in the United Kingdom were completed by Hungarian- or maybe German-speaking users. With regard to the geographical distribution of the users from Germany it is worth mentioning that only $6 \%$ of almost 1,000 respondents were inhabitants in the area of the former GDR or resided there at the time of completing the questionnaire. A certain share of the number of Berlin respondents, who amounted to $10 \%$ of all users in Germany, is added to the number of users from the area of the former GDR. The highest numbers of users of the application were based in Bavaria, Baden-Württemberg and North-Rhine Westphalia. In Austria 1,287 respondents replied to the questions, so Hungary's neighbour ranks 2nd after Hungary on the list of countries where Vokskabin questionnaires were completed. Interestingly, in Vienna a mere 1,031 people voted at an embassy or consulate. By contrast, 953 people completed the Vokskabin general election questionnaire in the Austrian capital, which is $74 \%$ of all questionnaires completed in Austria.

Compared to the statistical data of the general election questionnaire, Vokskabin's foreign usage levels show a significant divergence regarding the European parliamentary elections in May and the local elections in October. Between 12 and 25 May 2014 the questionnaire, which likewise contained 26 questions, was completed by 825 people in total, 550 of them based in Hungary. In absolute terms, the highest number of completed questionnaires (73) was submitted in Germany, followed by Spain (45), Austria (34) and Greece (16). Ranked in relation to population, however, this list changes: Austria first, followed by Greece and then Spain. The low user numbers are also reflected in the limited interest shown in the European parliamentary elections. In Hungary the voter turnout for the European parliamentary elections was even below 29\%, which falls significantly short of the EU average of 42.6\% produced in 2014 (European elections, 2014: 40\%). The low use of the Vokskabin questionnaire for the European parliamentary elections was influenced by two additional factors: firstly, in contrast to the election in April the Vokskabin questionnaire on the European parliamentary elections received no media coverage and it was only the Vokskabin Facebook ${ }^{5}$ page that was able to draw a certain number of responses from users. The second influencing factor lies in the fact that numerous other similar voting guides started operating at European level at the time of the European parliamentary elections, all of which represented a significant source of competition to Vokskabin. In this respect, it is worth mentioning some projects such as EUvox 2014 ${ }^{6}$, where the Vokskabin editorial team and the students of Andrássy University [Andrássy Egyetem] contributed to compiling the Hungarian party profiles, and Europrofiler, which is also the result of international collaboration. ${ }^{7}$

The 3rd and last election in 2014 took place on 12 October. For this, Vokskabin's editorial team compiled a questionnaire with 39 questions which was launched at the press conference held on 1 October at Andrássy University. Consequently, the study refers to data collected between 1 and 12 October 2014. At the local elections, where the representatives of the local councils and the mayors were elected, the turnout of the electorate was $44.29 \%$. This limited interest was reflected in the numbers of respondents to the Vokskabin local election questionnaire. During the surveyed period, in Hungary the local election questionnaire was completed by a mere 473 people, who, in contrast to previous figures, account for $61 \%$ of all completed questionnaires. The German figure of 185 users $(23.9 \%)$ took second place, and in terms of the foreign figures first place, respectively. Austria came 2 nd with 45 respondents and Switzerland 3rd with 14 users. Taking into account the number

\footnotetext{
${ }^{5}$ https://www.facebook.com/vokskabin.hu

${ }^{6} \mathrm{http}: / /$ www.euvox2014.eu/

${ }^{7} \mathrm{http}: / /$ www.euprofiler.eu/
} 
of inhabitants of Austria and Germany, the holders of the first two places switch again. With regard to the German regions the local election questionnaire yet again reveals a "West German" dominance: The highest numbers of users of the application were recorded in North RhineWestphalia and Bavaria. In the area of the former GDR the ratio of users was $9.5 \%$ in total, a figure that, as previously, has to be supplemented by one part of the Berlin respondents (12\%). In Austria the most users interested in the Vokskabin questionnaire for October were located in Vienna and in Graz.

\subsubsection{Vokskabin usage levels in Hungarian towns and cities}

As was the case with the European parliamentary elections, the little interest displayed in connection with the local election questionnaire was partly due to the fact it received no media coverage. The low turnout at the election is further testament to the fact that the interest of the electorate in the local elections had dropped significantly by October, which can be ascribed to the multi-election year having a demotivating effect on voters.

Vokskabin's sets of questions revealed an interesting pattern regarding the election turnout of Szentendre inhabitants. For a period of nearly 5 weeks during which the set of questions for the general elections was used, Szentendre was amongst the most active towns and cities. A total of 13,300 completed questionnaires means that the highest number of users is located in Budapest. However, when considering the number of users in relation to the size of the population, we get a different picture: $0.76 \%$ of all Budapest inhabitants completed the Vokskabin questionnaire. In Pest county, where Szentendre is located, a total of 2,247 persons replied to Vokskabin's questions that focused on the general elections. If we rank the most active towns and cities in relation to the number of their inhabitants, Vác takes 3rd place. In Vác we counted 234 users, a figure that corresponds to a turnout of $0.70 \%$ measured against the total number of Vac's inhabitants and which falls short of the Budapest figure only to a very small extent. The 2nd most active town was Budaörs, where Google analytics registered 237 users, a figure which corresponds to a turnout rate of $0.85 \%$, putting it ahead of Vác and Budapest. In Vokskabin's mobilisation "race", Szentendre came first in the ranking: 242 users completing the general election questionnaire corresponds to $0.95 \%$ of the total number of Szentendre's inhabitants. Not only did the inhabitants of Szentendre show greater interest towards Vokskabin but also towards the general elections: On 6 April, participation in Szentendre was $69.26 \%$ [23] which is more than 8 percentage points above the national average (61.73\%).[15] However low the figure of 11 European election questionnaires is in itself, it still means that Szentendre was once again the most active amongst Hungarian towns and cities. At the local elections, 276 out of a total of 473 respondents completed the questionnaire from a Budapest IP address. Defining any significant geographical features of the remaining users is not possible since the remaining 197 questionnaires were completed in 60 different towns or cities.

The reasons for the higher than average turnout rates in the thriving sub-region of Szentendre can probably be attributed to its distinguishing features. These include aspects such as a well-organised civil society, high levels of schooling and a high number of persons within the total population holding a knowledge-based management or intellectual position.[10] In addition to this, the number of graduates in Budapest and its surrounding area is high, especially in in Szentendre and in Pilisvörösvár.[11] Moreover, Szentendre is the perfect example for a small town located outside Budapest with its inhabitants employed in the capital and belonging to highly educated social groups.[3] As a matter of fact, this trend further benefits from Budapest's proximity. Another important Szentendre characteristic is the local Serbian ethnic minority living on the "peninsula", where the contemporary Serbian cultural, political and religious life was given room to unfold. One 
of the reasons why the Serbian ethnic minority is an interesting group in terms of voting behaviour lies in the fact that its members have extraordinarily high levels of schooling.[24] In addition to the Serbian minority there is a Croatian, a Polish, a Greek, a Romani, a Romanian and a Slovak minority. Each of them has a separate local self-government as of October 2014.[16] Seen from a historical perspective the diversity of these ethnic minorities is no definite proof of high election turnout rates[8] but Szentendre's developed political culture has a stimulating influence on its inhabitants.

\subsubsection{Vokskabin use levels in Hungary for the counties and Budapest}

Summing up the Hungarian users of the three Vokskabin questionnaires we arrive at the following statistics on the counties in relation to their population: The most active counties are Vas county with 617 completed questionnaires, followed by Pest county with 2,370 users and Fejér county in third with 832 users. When looking at Budapest as a county, this picture changes and Budapest takes the lead with 14,475 users. The most passive regions in terms of completed Vokskabin questionnaires are Nógrád county in the north of Hungary with 70, Szabolcs-Szatmár-Bereg county in the north of the Great Hungarian Plain with 295 and Borsod-Abaúj-Zemplén county, which is also in the north of Hungary, with 486 users. When summing up the total user data an east-west and a north-mid-west division emerges, which also mirrors the state of economic development in the whole country. Consequently, it can be stated that the use levels of Vokskabin in Hungary are higher in the economically more developed counties including Budapest, while the number of completed questionnaires is lower in the more underdeveloped regions of the country.

The first set of questions deployed after the general elections dealt with the implementation of gender equality in Hungary and was presented to the public in a survey containing 21 questions that started on 4 June 2015. The questionnaire was completed by 24,712 respondents until 23 September 2015. The highest number of visitors to the site on one day (more than 17,000) was recorded on 7 July, when Index, the largest Hungarian online portal, reported on the questionnaire.

The examination of all Hungarian respondents at county level leads to similar results as in the past. Pest and Csongrád counties along with Budapest showed the highest activity levels. By contrast, the lowest numbers of respondents were recorded in the counties of Nógrád, Szabolcs-Szatmár-Bereg and Békés. Outside Hungary, user activity was highest in Austria, Great Britain and Germany.

\section{Results of the impact study}

The questionnaire survey on the effects of Vokskabin that was conducted in December 2015 was completed by 1,240 people. The demographic and regional features of Vokskabin users were confirmed by the impact study. Once again it was the daily internet users in the age range of 25 to 44 years who live in Budapest and in Pest county and have high levels of schooling (university graduates and graduates of other institutions of tertiary education) that completed the questionnaire. The over-65-year olds, the Romani (i.e. those who described themselves to this effect), those with low schooling and the inhabitants of Hungary's less developed regions were particularly underrepresented $^{8}$. Incidentally, this user profile dovetails with the user profile of the readers of index.hu.

\footnotetext{
${ }^{8}$ For further information about the user profile of VAAs in Western Europe see: S. Marschall (2014): Profiling Users. In, Garzia D., S. Marschall (ed.): Matching voters with parties and candidates, ECPR Studies, Colchester, 92-104.
} 


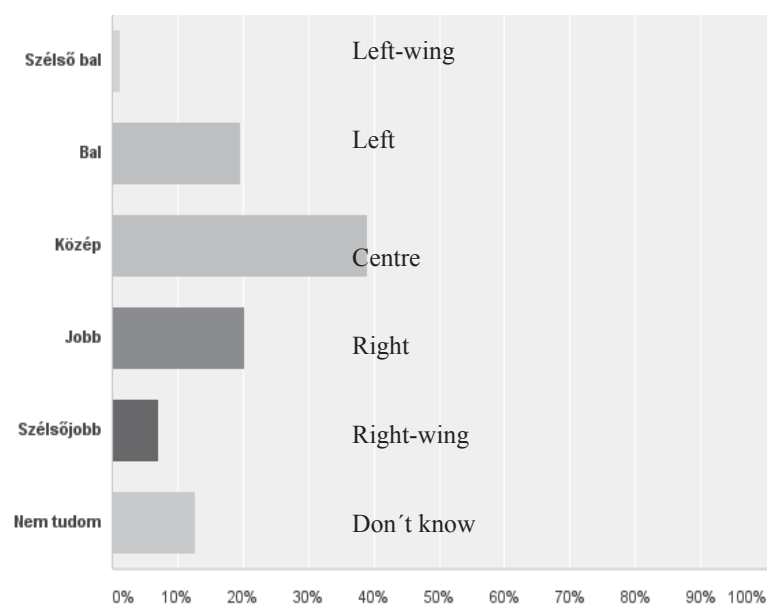

Figure 2: Political ideology of respondents

On the political ideology spectrum, nearly $40 \%$ of the respondents chose the political centre, while $20 \%$ chose the left side and $20 \%$ the right side. $7 \%$ considered themselves belonging to the far right. $13 \%$ were undecided.

\begin{tabular}{|c|c|c|c|}
\hline Answer Choices & \multirow{5}{*}{$\begin{array}{l}\text { Agree } \\
\text { Partly agree } \\
\text { Neutral } \\
\text { Partly } \\
\text { disagree } \\
\text { Disagree }\end{array}$} & \multicolumn{2}{|c|}{ Responses } \\
\hline Egyetértek & & $39.87 \%$ & 492 \\
\hline Inkább egyetértek & & $32.50 \%$ & 401 \\
\hline Semleges & & $20.58 \%$ & 254 \\
\hline Inkább nem értek egyet & & $3.08 \%$ & 38 \\
\hline Nem értek egyet & No & $3.97 \%$ & 49 \\
\hline Total & & & 1,234 \\
\hline
\end{tabular}

Figure 3: Effects on knowledge

The first question relates to the political knowledge of the user: "To what extent do you agree with the statement that Vokskabin is an important application that helps differentiate between the positions of political parties?" It was answered by 1,234 users. $40 \%$ of the respondents agreed and $32.5 \%$ partly agreed with the statement. $7 \%$ of those surveyed disagreed or partly disagreed with the statement. $20 \%$ considered the effect of Vokskabin as neutral.

\begin{tabular}{cll|lr}
\hline \multicolumn{2}{c|}{ Answer Choices } & & Responses & \\
\hline \multicolumn{1}{c|}{ Igen } & Yes & $\mathbf{2 0 . 0 2 \%}$ & 247 \\
Nem & No & $\mathbf{6 4 . 3 4 \%}$ & 794 \\
\hline Nem tudom & & $\mathbf{1 5 . 6 4 \%}$ & 193 \\
\hline Total & & & $\mathbf{1 , 2 3 4}$ \\
\hline
\end{tabular}

Figure 4: Effects on party vote 
In the context of examining the voters' decision-making process, when asked the question "If general elections were to be held in Hungary next Sunday, would you let your voting decision be influenced by the Vokskabin results" $20 \%$ of the 1,237 respondents answered yes. $15 \%$ of those surveyed were unable to define the extent of influence that the application exerted on their selection of a political party.

\begin{tabular}{|c|c|c|c|}
\hline \multicolumn{2}{|l|}{ Answer Choices } & \multicolumn{2}{|c|}{ Responses } \\
\hline Pozitivan & Positive & $33.23 \%$ & 411 \\
\hline Negativan & Negative & $0.40 \%$ & 5 \\
\hline Nem befolyásolja & No effect & $\mathbf{4 6 . 4 0 \%}$ & 574 \\
\hline Nem tudom & Don't know & $19.97 \%$ & 247 \\
\hline Total & & & 1,237 \\
\hline
\end{tabular}

Figure 5: Effects on voter turnout

The question regarding voter turnout: "In your opinion does Vokskabin have an effect on voter turnout (i.e. does Vokskabin make someone go to the polls)?" 33\% of those surveyed think that the application had a positive effect on the turnout and $46 \%$ think it would not influence the turnout rate. $67 \%$ of the respondents would "complete a Vokskabin questionnaire again in the future". Only $2 \%$ of those surveyed refused the possibility of completing further questionnaires at some point in the future.

These results has shown similar to the effects pointed out in research studies in Western Europe ${ }^{9}$ that VAA usage contributes to higher turnout at elections and has positive effects on political knowledge.

\section{Summary and outlook}

Based on the use levels of Vokskabin we obtained a significant picture of both the foreign and the Hungarian figures. For the first set of questions, user activity outside Hungary was highest in Austria and Germany: In Austria 4.64\% of all users used the application, in Germany this figure was 3.35\%. For the April questionnaire, Szentendre turned out to be the most active amongst the cities and towns in Hungary. Outside Hungary, and in relation to the population of each country, the set of questions on the European elections was completed by most users in Austria, Greece and Spain. Like the questionnaire on the European elections from May, the questionnaire on the local elections similarly fell short of expectations. In Hungary merely 473 people completed the questions. By contrast, the rate of users outside Hungary increased by $39 \%$ compared to the previous 2 sets of questions: Looking at the foreign figures, first place goes to Germany with 185 users who completed the questionnaire, followed by Austria with 45 users. When looking at the users, a "West German" dominance regarding the European election questionnaire and the local election questionnaire can be observed as far as the regions of Germany are concerned. If a certain part of the Berlin users is included in the calculations, the ratio of those who completed the survey in the area of the former GDR exceeded the 10-percent mark by 1 or $2 \%$.

\footnotetext{
${ }^{9}$ For an overview about the positive effects of VAAs in Switzerland, Germany, Finland and the Netherlands see the study of Garzia et. al. (2014): The Impact of Voting Advice Applications on Electoral Participation. In, Garzia D., S. Marschall (ed.): Matching voters with parties and candidates, ECPR Studies, Colchester, 105-114.
} 
Examining all of the Hungarian respondents to the 3 sets of questions at county level, the counties of Vas and Pest and the capital Budapest emerged as the most active ones, whereas the counties of Nógrád, Szabolcs-Szatmár-Bereg and Borsod-Abaúj-Zemplén were the most passive. This points towards a chasm in the user population running between east and west and north-mid-west. The same kind of divide was characteristic for the user levels of the questionnaire on equality for men and women and the questionnaire on Hungarian Roma.

The changeable interest in Vokskabin can be explained by its novelty effect. In addition to pedagogues, teachers, artists and public figures, the media and the political stakeholders will have to show significant commitment in order for Vokskabin and voter guides in general to reach up to $20 \%$ of all voters, as is common in Western countries. The indispensable prerequisite for this process is the education of Hungarian society, in particular of its young people, whether in an institutional or a political context, which includes education and raising awareness on politics, public life and social studies in a spirit of "civic education" in order to promote social commitment.

In summary, similarly to Western Europe the application is expected to yield future positive effects both in terms of political knowledge and electoral turnout. The basic impact study shown above merely features trends that imply further studies and correlation analyses to be conducted in election periods that enable a more differentiated examination of voters (non-voters, undecided voters, voters with a strong party preference etc.).

\section{References}

[1] ASSOCIATION FOR EUROPEAN ELECTION OFFICIALS, ACEEEO, Vote Compass Hungarian general elections, 2010 [Választási Iránytü - Magyar Parlamenti Választások 2010]; http://www.magyarorszagvalaszt.hu/

[2] ALVAREZ, R. M., LEVIN, I., TRECHSEL, A. H., and VASSIL, K.: Voting Advice Applications: How useful and for whom? Journal of Information Technology and Politics, 11(1): 2012, p.82-101.

[3] BECSEI, J.: The geographical distribution of schooling in Hungary [A magyarországi népesség iskolázottságának területi viszonyai]. In: Kiss, A., Mezősi, G. - Sümeghy, Z. (ed.): Scenery, environment and society [Táj, környezet és társadalom]; Studies in honour of Ms. professor Ilona Keveiné Bárány [Ünnepi tanulmányok Keveiné Bárány Ilona professzor asszony tiszteletére] Szeged, 2006. p.99-107.

[4] BUNDESZENTRALE FÜR POLITISCHE BILDUNG (17.01.2014): Die Geschichte des Wahl-O-Mat; http://www.bpb.de/politik/wahlen/wahl-o-mat/176527/die-geschichte-des-wahlo-mat

[5] BUNDESZENTRALE FÜR POLITISCHE BILDUNG (22.01.2014): Die Nutzer des WahlO-Mat; http:/www.bpb.de/politik/wahlen/wahl-o-mat/177430/die-nutzer-des-wahl-o-mat

[6] CIVIL RÁDIÓ [Civil Radio], 117 Minutes: interview with Melani Barlai about the launch of Vokskabin on 6 March, 2014 [117 perc, Interjú Barlai Melanival a Vokskabin indulása alkalmából, március 6-án]; http://www.andrassyuni.eu/upload/File/Audio/2014/CivilRadio VokskabinInterview2014.03.mp3 
[7] DONAU-UNIVERSITÄT-KREMS Politikkabine, 2012, at; http://www.donauuni.ac.at/de/universitaet/netpol/projekte/id/10318/index.php

[8] EGRY, G.: The role of national and ethnic affiliation in voting behaviour in Hungary in the 20th century, 2006 [A nemzeti és etnikai kötődés szerepe a választói magatartás alakulásában Magyarországon a 20. században]. Budapest.

[9] EUROPEAN PARLIAMENT, European and national elections figured out, Special edition European elections, 2014; http://www.europarl.europa.eu/pdf/elections_results/review.pdf

[10] FORRAY, K.: Social and geographical factors influencing employment and unemployment; closing study of research no. OFA/6341/26, 2008 [A foglalkoztatottság és a munkanélküliség szerkezetét befolyásoló társadalmi-területi tényezők, Az OFA/6341/26 sz. kutatás zárótanulmánya.] Oktatáskutató és Fejlesztő Intézet [Institute for educational research and special needs]. Budapest, http://www.forrayrkatalin.hu/doski/OFA_tarsadalmi-teruleti.pdf

[11] FORRAY, K. and HÍVES, T.: The geographical correlations between schooling, employment rates and commuting, 2009 [Az iskolázottság, a foglalkoztatottság és az ingázás területi összefüggései] Szociológiai Szemle [Sociology Digest], 19(2): 42-59, http://www.szociologia.hu/dynamic/SzocSzemle_2009_2_42_59_ForrayK_Hives.pdf

[12] GEMENIS, K. and ROSEMA, M.: Voting Advice Applications and electoral turnout. Electoral Studies, 36, 2014, p.281-289, http://dx.doi.org/10.1016/j.electstud.2014.06.010

[13] HEINRICH HEINE UNIVERSITÄT, Philosophische Fakultät: Wissenschaftliche Forschung zum Wahl-O-Mat, 2014, http://www.wahl-o-mat.uni-duesseldorf.de/

[14] HUNGARIAN ELECTORAL COMMISSION [Nemzeti Választási Hivatal] Voting at embassies and consulates in 2014, 2014 [Külképviseleti szavazás 2014], http://www.valasztas.hu/hu/ogyv2014/859/859_0.html

[15] HUNGARIAN ELECTORAL COMMISSION [Nemzeti Választási Hivatal] (2014): Election of the members of the Hungarian parliament Voter turnout figures and ratios [A választáson megjelentek száma és aránya], http://valasztas.hu/hu/ogyv2014/858/858_0_index.html

[16] HUNGARIAN ELECTORAL COMMISSION [Nemzeti Választási Hivatal] (2014): Information on the election outcomes of the ethnic minorities in Szentendre [Tájékoztató adatok Szentendre települési nemzetiségi választás eredményeiről], http://www.valasztas.hu/dyn/onk14/szavossz/hu/M14/T126/tjknemz.html

[17] HVG (author not known): KSH [Hungarian Statistical Office]: 335,000 Hungarian adults with a registered Hungarian address live abroad, 11.07.2013 [335 ezer magyar lakcímü felnőtt él külföldön, 2013.07.11], http://hvg.hu/gazdasag/20130711_KSH_335_ezer_magyar_lakcimu_ felnott_el_ku/

[18] ISIDEWITH (2012): About us, http://www.isidewith.com/about/

[19] ISIDEWITH (2012): Frequently Asked Questions, http://www.isidewith.com/faqs/ 
[20] IRÁNYTÜ POLITIKAI ÉS GAZDASÀGKUTATÒ INTÈZET, 2011 [Compass Institute for Politics and Economic Research]: \{ut2]: http://iranytuintezet.hu/r\%C3\%B3lunk

[21] KFTKREÁTOR: Do up to 600,000 Hungarians work abroad? [Akár hatszázezer magyar is dolgozhat külföldön?] http://kftkreator.hu/cikk.html

[22] POLITICAL CAPITAL, 2001: http://www.politicalcapital.hu/magunkrol/mi-a-politicalcapital/

[23] SZENTENDREI MÈDIAKÖZPONT ÉS KOMMUNIKÀCIÒS KFT: [Szentendre Media Centre Media and Communications Ltd] 2014: [The first data on the region arrive today] Már érkeznek az első adatok a térségből, http://tvszentendre.hu/hir/mar_erkeznek_az_elso_adatok _a_tersegbol

[24] SERBIAN SELF-GOVERNMENT in Hungary: http://www.szerb.hu/hu/

[25] WAGNER, M. and RUUSUVIRTA, O.: Matching voters to parties. Voting advice applications and models of party choice. Acta Politica, 47: 2012, p.400-422.

[26] WALGRAVE, S., NUYTEMANS, M. and PEPERMANS, K.: Voting aid applications and the effect of statement selection. West Eur. Polit. 32, 2009, p.1161-1180.

[27) WAHLKABINE: www.wahlkabine.at 